\title{
Interpreting Covid-19 Pandemic Issue from Islamic Tasawwur Perspective
}

\author{
Beta Pujangga Mukti ${ }^{1}$, Achdiar Redy Setiawan ${ }^{2 *}$ \\ 1) Center for Islamic Development Management Studies (ISDEV), Universiti Sains Malaysia, \\ Penang, Malaysia, ${ }^{2)}$ Universitas Trunojoyo Madura, Jl. Raya Telang, Bangkalan, Indonesia. \\ ${ }^{1)}$ beta.p26@yahoo.com, ${ }^{2)}$ achdiar.setiawan@trunojoyo.ac.id \\ *corresponding author
}

\section{ARTICLE INFO}

Article history

Received 10 August 2020

Revised 20 September 2020

Accepted 10 October 2020

Keywords

Tassawur

Covid-19

Islamic Wisdom

\section{ABSTRACT}

In general, this article aims to make sense of the various discourses that have emerged around Covid-19 from the perspective of Islamic tasawwur. In Islam's religious or spiritual aspect, the Covid-19 pandemic's meaning needs to be more deeply interpreted. Thus, this essay will focus on this meaning based on Islamic tasawwur. In Islam, every Muslim believes that every event always provides a message or wisdom. Behind the "black" side of the Covid-19 pandemic, there must be "white" or a glimmer of light that this crisis will lead to opportunities.

This is an open access article under the CC-BY-SA license

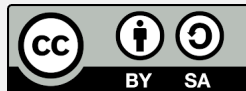

\section{Introduction}

Covid-19 (Corona Virus Diseases-19) originally appeared in the middle of December 2019 at Wuhan, Hubei Province of China. In subsequent events, this virus spread to various countries around the world. More than a million cases of Covid-19 have been reported in more than 200 countries. World Health Organization (WHO) then label the virus spread as a pandemic on March 11th, 2020. According to the latest data on September 2020 quoted from sources, Johns Hopkins University (Baltimore, United States) shows the number of Covid-19 victims reaches over 23 million.

The movement of the plague is so fast. It spreads drastically throughout the earth. It is a terrible phenomenon that may not have occurred to humans. It shows how a super-micro creature of God has shaken the majority of the earth's population. The effect is a domino, moving wildly in various fields. The impact of Covid-19 touches all aspects, starting from health issues, then on elements of the economy, education, science, social, culture, and religion. Economic business activity stops. School activities had to be stopped. Social lives are restricted. People are asked to stay at home. Mosques and other places of worship were closed. The way people interact is becoming different to avoid the spread of this deadly disease. Panic swept over the heads of the majority of the earth's population.

The Covid-19 outbreak is a test of life for humans in all countries. It has had an impact on all sectors of life, especially the socio-economic sector. Many people experience a tough life during this pandemic. Working outside is limited because of following social and physical restrictions. Many people have lost their jobs or sources of income. As quoted from the newspaper The New York Times, economists say, "this pandemic has led to socioeconomic disruption globally. If this plague is endless, a country will experience a crisis 
". However, from the negative impression regarding the Covid-19 outbreak, a positive image can be used as a lesson.

Covid-19 outbreak takes humans to (forced) to remain silent for a moment to reflect on life. Muhasabah (self-reflection) activity, a kind of deep contemplation, is vital to do occasionally as often as possible by every human being. Emha Ainun Najib, cultural observer, and the spiritual teacher said that living in silence to find out what is actually the crowd's content.

Modern humans, who are required by conditions to always move fast, are dynamic and are pressed for time, are forced to brake most of their activities these days. The Javanese philosophy of alon-alon waton kelakon (let it be slow as long as it survives), which was considered ancient during the recent period, has found its relevance again. In fact, a slowing down is needed by humans to find back to its true nature. The speed, haste, and all the attributes that characterize most modern humans must be admitted to make humans look inward more intensely.

When situations require everyone to limit their daily activities, this is the right time to do a lot of self-evaluation - reflecting on everything that has been done throughout the given age. The reflection comprises self, family, other humans around us, nation, the universe and particularly about God and religious institutions. People should internalize one of Sunan Drajat's messages: heneng-henung (in a state of silence or meneng), we will get meaning of life quite profoundly. In the natural form of silence, we will precipitate the whole nobleness with all the depth of devotional thought, heart, and acts in harmony.

Furthermore, the Covid-19 pandemic provides a positive message and great opportunities that could be raised. Bryan Walsh (2020), an economic expert, wrote an article on Axios, that its pandemic left a positive impression in political, cultural, and socio-economic aspects. Some examples of positive things poking, among others, firstly, many people live their sense of social empathy by assisting the victim of Covid-19, especially those that require economically. Second, from an environmental perspective, we feel that nature can take a short break to return clean from air pollution, as noted by environmentalists and energy sources. Geman [1] also expressed his concern about environmental aspects in an article on Axios. Thirdly, awareness of spirituality becomes stronger and higher. The belief in God as a place of refuge is getting higher in order to be protected from this deadly disease.

To illustrate how the crisis could make better opportunities in the future, we can refer to a history of deadly outbreaks in Europe some decades ago. This history is well narrated by Yudi Latif [2] in his article, which describes how terrible Europe's events at that time, to be precise, in Sicily's city. Nearly one-third of Europe's population died due to plague or a disease so-called "Black Death" (Black Death). The entire body condition of an infected person is the black bubble. However, almost five years after the "Black Death" era, marked by significant technological development advances, such as gunpowder, a printing press, and a compass. These developments paved the way for market expansion and drew for the nation state's birth and the industrial revolution.

The "Black Death" pandemic that has occurred in Europe can be equated with Covid19 outbreaks that are happening at present, maybe even more terrible. Thus, it is necessary to disclose and realize a light or great opportunity that will be obtained behind the pandemic.

\section{Method}

In general, this article aims to make sense of the various discourses that have emerged around Covid-19 from the perspective of Islamic tasawwur. In Islam's religious or spiritual aspect, the Covid-19 pandemic's meaning needs to be more deeply interpreted. Thus, this 
essay will focus on this meaning based on Islamic tasawwur. In Islam, every Muslim believes that every event always provides a message or wisdom. Behind the "black" side of the Covid-19 pandemic, there must be "white" or a glimmer of light that this crisis will lead to opportunities. Referring to Allah SWT's statement in the Qur'an, after trouble comes, ease will come (QS An Nasr 94: 5-6). As a source of Islamic knowledge, the Qur'an has explained how a Muslim should behave in facing difficulties and rise to a better direction in the future. This guide has become Islamic way of life for every Muslim to act and apply it in life

\section{Results and Discussions}

This section elucidates Black-and-White Covid-19 in Islamic Tasawwur Perspective. Covid-19 provides a space of looking inward intensely. What is the meaning of our life? How useful is our life? How close are we to parents, siblings, children, and wives as well as neighbors amid our busy day? Fundamental questions of this kind are relevant to be asked again to each self.

During the struggle, a life that causes human time to fulfill life necessities is neverending; this looks inside activity doesn't get sufficient allocation. As a result, many social phenomena make humans uprooted and distant from self-concept ideals and their closest circle: family. This self-reflection (muhasabah) is essential to continue, especially when we are given time to pause during the Coronavirus pandemic. Allah SWT said in Qur'an surah At Taubah 126:

"And don't they (the munafiq) notice that they are tested once or twice every year, then they don't (also) repent and don't (also) take lessons?"

Rasulullah PBUH also said about the importance of this practice of self-reflection, as in the following hadith:

The Prophet SAW said: "Two pleasures, most people are deceived by both, (namely) health and free time" from Ibn Abbas RA. (narrated by Bukhari).

Hence, the Covid-19 phenomenon required tasawwur or the right world-view for responding to the situation. In this tasawwur perspective, Syed Muhammad Naquib AlAttas [3] explained that "Humans need to recognize the essence of self and also creation". The process of knowing the nature of the self, means recognizing the meaning of the essence of human creation to the earth, namely as servants (abdullah) and caliphs (khalifatullah fil ardh). Likewise, Allah SWT is the Supreme Creator who wishes to create anything on this earth. Any creation in that world must have purpose and intention. Horowitz [4] explains that tasawwur also touches on life goals that involve universal and general decisions. A person's view of nature summarizes his educational, political, philosophical, and moral attitudes in addition to other matters". The essence (hakikat) of its fundamental concept is needed to be understood by humans to obtain a True view, which will form the actions and behavior in life sequentially. To achieve this meaning and understanding of this essence, humans need to know the tasawwur and the essential elements in tasawwur. At the beginning of the discourse, it is substantial to take into account understanding tasawwur. Harun Din [5] defines tasawwur as follows;

"In terms of language, tasawwur means the visual image of something. When the words tasawwur are combined with the 'Islamic' word, it becomes "Islamic 
tasawwur." It can be interpreted as a description of Islam's proper form. Thus, Islamic tasawwur aims to explain the Islamic Right as it is overall".

Sayyid Qutb [6], which is referred to as the first stone of the theoretical foundations Islamic tasawwur or in terms of at-tasawwur al-Islami al-Wujud, explain tasawwur as follows:

"A set of fundamental beliefs in the mind and heart of a Muslim who became his point of view in the act and saw the presence of nature. This belief also leads to a picture of the One who is behind this nature, namely God Almighty, who has created and governs the universe. The relationship between the existence of the earth and Allah the Almighty has also been arranged in such a way as to be properly understood ".

Another scholar, Muhammad Syuki Salleh [7] explains that "Easily, Islamic tasawwur here means a picture of the true form of Islam, which explains the whole principles of Islam completely and comprehensively so that people who understand it can share it". Moreover, Muhammad Syukri Salleh [7] also put forward the elements of the Islamic tasawwur principle:

"Al-Qur'an, directly and indirectly, describes the existence of three main points of Islamic tasawwur. The first thing is that Allah SWT is the creator; second, that humans are creatures; and third, that the natural resource is also a creature who, like humans, submits obediently to Allah SWT".

Furthermore, Muhammad Syukri Salleh [7] describes several elements of the Islamic tasawwur principle. First, Allah is the Creator. This is the divine essence that every human being must believe in. By believing in Allah SWT's essence as the creator, there will be a vertical relationship between humans (servants) and Allah SWT (creator) or called hablumminallah. Elements of the base form a view of human life to be sure that something created by God is to man's destiny and God the Creator did not create anything in this world in vain, but there are goals and objectives. Allah SWT stated in Qur'an Surah Al-Imran, 3: 191:

"(It is) those who remember Allah standing or sitting or lying down and they think about the creation of the heavens and the earth (saying):" O our Lord, you did not create this in vain, Glory to you, then save us from the torments of hell. "

In this aspect of Godliness, several things can be raised. First, the Covid-19 outbreak reminds us of how powerful God is. Pride, arrogance, and all the things that glorify the greatness of the self these days can't be relied on anymore. Creatures as small viruses sent by God around the world can take the lives of all people, without exception. It can even touch the clever and possessed (materially).

By hablum min Allah, this pandemic makes people seem to need God more. The fear of being impacted by this disease also makes prayer sounds louder. The process of endeavoring to find ways of eradicating or preventing the virus in a scientific rationalistic manner goes hand in hand with fervent, religiously spiritual prayers. This condition reaffirms that God does not need anything from humans. God has no interest in humans. On the contrary, in terms of fitrawi, human beings need a belief in the existence of Causa Prima, a Supreme Being, having power above all that exists. Hence, God confirmed its 
existence. There is a Reality (big R), the One, who governs the creation of the heavens and the earth in it. A basic or main foundation of religion brought through the mediation of the Prophet and His Messenger: the teachings of Tawhid.

The commandment to believe and fear Allah's power will always be contextual as long as humans live. No power is greater than His power over the heavens and the earth. Let's keep remembering this message of monotheism with every breath. Remember when Allah said in QS. Al-Hashr 18, for instance:

"O you who believe, fear Allah and let each one pay attention to what he has done for tomorrow (hereafter), and fear Allah, Allah knows best what you are doing. "

The second element of the Islamic tasawwur principle is about humans as creatures. It means that humans-created has two main tasks or functions, namely slaves, to worship (Qur'an Surah Adh-Dhariyat, 51:56), and became caliph for the prosperity of the earth (Qur'an Surah Al-Baqarah, 2:30). In the Islamic conception, God gives humans two main functions: servants of God (abdullah) and representatives of God on earth (khalifatullah fil Ardh). As the first assignment as a slave, as described in the first principle element, build a vertical relationship with Allah SWT. As servants, humans are in a passive position, the awareness that God created humans. Therefore, they must submit and obey God's power. Faith in the oneness of God (Tawhid) is the subject of the teaching. For the second task as caliph, it is not just too meaningful prosperity of the earth but also meaningful in muamalah, building relationships with fellow human beings. Marshall Hudgson [8] states that the concept of man in the Qur'an is "very human, even social." It can be concluded that the human's role as caliphs in the social or muamalah aspect is emphasized. The function of being caliph implies the nuances of active human consciousness. Man is an extension of the hand and is given a delegation of God's authority to lead the earth's governance.

This second element of tasawwur tells us that the Covid-19 pandemic opens our eyes to how to view our relationship with humans and the universe. By hablum min an naas, we often angry instead of friendly. Empathy and sympathy began to fade.

Therefore, when looking at the present conditions, there is deep anxiety. The earth and all its inhabitants (especially humans) tend to lead to stifling and worrying conditions. Destructive behavior towards the environment, personal and group egoism, corrupt, and manipulative actions are daily news dishes in the mass media. Over time, all actions that are contrary to human values are considered normal things. All destructive habits are the beginning of a series of calamities, riots, and disharmony in society.

Humans are creatures that are created in the best possible form of creation. God sends humans as His representative (khalifatullah $f i$ al-ardh). Humans should interpret the process of their creation to transfer the values of goodness to the environment. With a set of hardware (physical/body) and software (reason and conscience) in a perfect combination. Humans are able to lead the management of the earth and its contents according to God's will. Nevertheless, what is immoral, this ideal condition seems completely invisible amid the domination of behavior that eschews religious values. Humans seem to be deprived of their basic values to interpret God's commandment to become grace for all nature (rahmatan lil alamin).

The third element of the Islamic tasawwur principle is the source of nature as a creature. Muhammad Syukri Salleh [7] explains: 
"Allah SWT provides natural resources for the benefit and convenience of humans so that people can realize the nature of Allah SWT, who is the most compassionate and the most merciful. Even so, humans are still bound by the rules and limitations that have been determined by Allah SWT in exploring and using the natural resources of His creation (QS. Al-Jathiyah, 45:13)".

As representatives of Allah SWT, men connect themselves with fellow humans and natural resources (hablum min annas), which are horizontal. They interact with fellow humans and natural resources with a full sense of responsibility, trust, character, and full ethics. This is following the role of khalifatullah fil ardh. Allah SWT said in the Qur'an Surah Al An'am, 6: 165 \& Qur'an Surah Yunus, 10:14:

"And it is He who made you rulers on earth, and He exalted one part of you over some (another) several degrees, to test you about what He gave you. Surely your Lord is swift to torture, and indeed He is Forgiving, Most Merciful".

"Then We made you (as their) substitutes on the earth after them so that We would pay attention to how you did."

The two verses emphasize that humans are sent to the earth, given advantages compared to other creatures, to become caliphs (leaders) who have the responsibility and mandate to preserve and prosper the earth. The Covid-19 pandemic reminds people of context hablum minal alam (a good relationship with the universe). Various global warming issues, deforestation, and other environmental problems show how barbaric our treatment of nature is. We often exploit nature extractive. Land, water, air pollution, and global warming are the real effects of humane treatment on the universe.

In this pandemic era, it seems that the earth is looking for a new balance when the majority of humans are "forced" for a moment to break their activities, especially those with destructive nuances. Humans can pay more attention to their family, neighbors, friends, and the surrounding environment more intensely during this break. The ability to empathy needs to be turned on to give a little of its property to other humans affected by slowing down activities (including the economy).

The third principal element of Islamic tasawwur, is used to view and analyze and interpret the issue of Covid-19. Covid-19 has two points of view, the positive (white) and negative (black) side. From the perspective of Islamic tasawwur, awareness of religion, and the belief that Allah SWT is the creator of every creature and universe is necessary. A Muslim must believe that in every creation, there is a purpose and good intention. Likewise, with the Covid-19 outbreak, there must be a lesson for people who want to think.

The existence of Covid-19 is not a wasted creation but has a purpose and intention. Only Allah Almighty alone knows what the intent and purpose actually, but the human endowed with the brain to reflect on the creation of everything, Covid-19 entailed. Probably, behind this virus's result, Allah Almighty is testing people and especially those who believe to get back to nature, namely monotheism, to build relationships vertically by Allah SWT. "Even people who are mentioned by al-Qur'an as an atheist who believes that life is only determined by physical factors when they are in difficult circumstances or pressed, they believed in the strength and needs help from something that is metaphysic" [9].

Additionally, the existence of Covid-19 also builds a horizontal relationship between humans and humans as well as humans and the natural environment. As stated by Bryan Walsh [10] in the previous discussion, this positive impression of Covid-19 has led to 
changes in socio-economic aspects. As was seen, nowadays, many people have a sense of social care. There are many social actions to assist in the form of food, money in cash, and other helpful act to people who get in trouble during the pandemic. Likewise, with the surrounding natural conditions, the Covid-19 outbreak reduced air pollution due to vehicle fumes and refinery fumes. During this movement restriction command, people's reduced activity makes nature allowed to take a break from human activities that destroy the surrounding environment.

Awareness of a vertical relationship with Allah SWT delivers the great message that everything created by Allah SWT is not for human sadness and badness but a blessing for humans in particular and in general for the universe [8]. Moreover, by acting as a caliph to help fellow humans in the social and muammalah aspects, horizontal relations with fellow humans also deliver a positive way of thinking. Likewise, humans are obliged to have character, ethics, responsibility, and trust in protecting and using natural resources with natural circumstances. This awareness has formed tasawwur or a way of life in those who understand it. Covid-19 may be a life's test and a lesson for humans, but it is a blessing for nature.

As a Muslim, man/woman must believe that life's test given by Allah SWT is a form of the love of Allah SWT for his servant. So the servant returns to hope and ask only from Allah the Creator. Allah SWT said in the Qur'an Surah Al-Baqarah, 2: 155 and 153:

"And indeed We will give a trial to you, with little fear, hunger, lack of wealth, souls and fruit. And give good news to those who are patient".

"O you who believe, make patient and pray as your helper, verily Allah, and those who are patient."

Moreover, Allah Almighty created the danger of disease, certainly also provide medicine to heal. Allah SWT states in the Qur'an Surah As Syuara, 26:80, which states: "And when I am sick, He is the One who heals me."

In the context of the Covid-19 disease outbreak, although it is not directly mentioned in the Qur'an, interpretation QS As Syuara 80 explains that Allah SWT has provided the medicine for all illness or diseases. Even though the Covid-19 vaccine has not yet been discovered until this day, we have to believe that Allah SWT has provided the cure and human efforts, medical science experts are working on it.

So the interpretation of the Covid-19 issue from the Islamic tasawwur perspective can be extracted. First, again, we realize that Allah Almighty has created Covid-19 to think and take lessons. More specifically, Allah SWT asks that man always asking for help only from Allah SWT. Thus, as Brandon [11] claimed, it makes people have a spiritual understanding and the expectation (hope) suffering life path.

Moreover, in Covid-19, there is an increase in the awareness of mutual help people in economic trouble. It includes the government itself by issuing assistance to its poor people during the restriction movement order. For instance, the worship restriction in the mosque implied that Allah SWT does not want people to forget the humanitarian aspects [12]. Allah SWT said in Qur'an Surah Al-Imran, 3:92): "You may never come to virtue (which is perfect) before you spend a portion of the wealth you love. And whatever you supply, then verily Allah knows".

Apart from worship that is vertical, don't forget about horizontal prayer in nature. Men/Women should balance both aspects; Islam is tangible in the mosque alone. More far away, it delivers rahmatan lil'alamin, mercy to the worlds, which also consider the human aspects. 
Furthermore, from a positive impression of nature, now humans again realize the importance of keeping the environment that is not polluted, preserving nature, and maintaining the natural ecosystems. Before the outbreak of Covid-19 occurred, humans' acts tend to destruct the untouched preserve in terms of black or negative impressions. The air is polluted due to uncontrolled fumes from vehicles and refineries. We shall see that when natural destruction, humans activities tend to reduce, nature can break moment. The air is clean again, and the forests are again functioning as the lungs of the world.

Based on the analysis of the three elements of the Islamic tasawwur principle in seeing the black-and-white issue of Covid-19, several recommendations can be taken as guidelines. First, Muslims need to take care that the Covid-19 pandemic is a momentum to make people have a deep spiritual understanding to build relationships vertically by Allah SWT. It is believed that this plague has become the destiny of Allah SWT. It may be a test of a Muslim's faith; it may also be a blessing for all nature. Second, humans also need to build relationships with fellow humans horizontally by having a sense of care in the human aspect (muamalah). Third, building a relationship with nature, that is, humans must have a sense of responsibility, trust, and good character and ethics in protecting and using nature not to cause damage to the earth.

\section{Conclusion}

It can be concluded that the Covid-19 outbreak needs to be seen not just in terms of the negative side, but also from the bright side. As a Muslim, we must believe that Allah SWT creates everything in vain; there must be a purpose and good intention. The ontological view (tasawwur) of Islam to interpret the Covid-19 pandemic needs to be put forward. From Islamic tasawwur, the Covid-19 outbreak has wisdom and can be a lesson for every human being. First, it delivers spiritual understanding and hopes to Allah SWT to build relationships vertically or called hablumminallah. Second, understanding human duties, namely, apart from being a servant to worship, as God representatives on earth maintain a horizontal relationship, both with fellow humans (hablum min an naas) and with the natural surroundings (hablum min al alam). Third, Covid-19 is a momentum for humans to protect and use natural resources with a full sense of responsibility, trustworthiness, character, and ethics. Do not ever destroy the environment.

Finally, "religion" (in this context: Islam) in the most profound spiritual consciousness is a way provided by God for the common good of all inhabitants of the universe. God does not need humans and other creatures. God's interest is only to ensure that the entire creation of the heavens and the earth is actually in line with the result of man and nature. In this consciousness, religion is not seen as imprisoned dogmas and full of binding mechanical rules. The ultimate goal of faith is ultimately for human happiness and wellbeing. Religion exists not for the benefit of God since God does not need anything from humans. Even in the form of a small defense, God does not need it.

Religion is a path, a guide, a guide (hudan lin naas) towards belief in God's existence, Causa Prima, the essence who created man (where it comes from), and where it will go the end. So science also needs to place (the intention) of God in all fields of its philosophical search, either ontological, epistemological, axiological, and methodological aspects.

In addition to previous reflections, it is also essential to remember Kanjeng Sunan Dradjat's seven messages when paying attention to the various phenomena surrounding the Covid19 pandemic. This seven message is relevant to invite Indonesian people to find their true self. This golden opportunity through the availability of time for intensive contemplation during this pandemic can be used to absorb the critical advice of one of the waliyullah who spread Islam in Java: First, Memangun resep teyasing sasomo (we should 
always delight others). This message is so relevant for us to do in our daily practice. The statement to not only focus on oneself (egocentrism) but to think about and please the people around us. It is in line with the Prophet Muhammad SAW's message, who said: "khoirunnaas anfauhum linnaas," that the best human being is he who gives the most significant benefit to humans and the surrounding environment.

Second, Jroning suko kudu eling lan waspodo (in a happy atmosphere, we must still remember Allah and must remain vigilant). Eling (remember Allah, dzikrulllah) and waspodo (vigilance) are practices that must be upheld in whatever situation we face. When we are happy, happy, no need to express it too much, especially when we are concerned about this kind of pandemic condition; this vigilance is also manifested in efforts to prevent the outbreak of the disease caused by Covid19. Wearing a mask, washing hands frequently, social distancing, and the like which are medically believed to avoid attacks need to be taken seriously and istiqomah.

Three, laksitaning subroto tan nyipto marang pringgo bayaning lampah (on the way to achieving lofty ideals, we don't care about all the obstacles that stand in our way). It could be that the pause button that Allah pressed for humans in various corners of the universe is a challenge that must be faced. Students cannot typically study in classrooms. Entrepreneurs do not quickly move to run their business. Daily workers do not get a decent living for their daily needs. However, creativity needs to continue to emerge. Humans are equipped with a reason (and conscience) to look for new ways to achieve the lofty ideals of life.

Four, mepper hardaning pancadriya (we must always suppress or restrain our passions). This pandemic period is the right moment to practice lust control. The ability to be patient and pay attention to others around us during this pandemic's tempo is a fruit we can learn to exercise this control of our passions.

Five, Heneng-Hening-Henung (in a state of silence, we will find deep silence) will achieve lofty goals). As explained above, the intensive activity of contemplating within is a way to find authenticity. Whoever knows himself will know his Lord (man 'arofa nafsahu faqod 'arofa rabbahu"), that is the expression of the great scholar Yahya bin Muadz Ar Razi who is famous among Sufism experts.

Six, mulyo guno panca waktu (physical and mental happiness we will get only by praying five times a day). This message was in line with Qur'an Surah Al Baqarah verse 153 when Allah SWT said, "O people who believe, be patient and pray as your helper. Verily Allah is with those who are patient. When this epidemic infiltrates many niches of life, submission through prayer and patience will be a sustainable solution to all the life problems that come.

Seven, Menehono teken marang wong kang wuto, menehano mangan marang wong kang luwe, menehano busono marang wong kang wudo, menehano ngiyup marang wong kang kudanan (Give sticks to blind people, feed hungry people, give clothes to people who have no clothes, and provide protection to people who suffer). The final message of Kanjeng Sunan Dradjat can not only be taken literally. Menehono teken marang wong kang wuto can be interpreted as helping people who are weak and needy. The stick for the blind is a guide for walking, so this can also be interpreted as teaching knowledge to people who are not knowledgeable. Menehano mangan marang wong kang luwe need to mean that humans should not only think about their own stomach or prosperity but need to learn to pay attention to the people around them who need a helping hand. Menehano busono marang wong kang wudo is how we give concern for the condition of people who are less able to cover their bodies or embarrassment with appropriate coverings. Finally, protecting marang wong kang kudanan is a message to provide shelter and protection for other human beings to ensure their humanity's safety. 
Finally, may this be the time for us, as human beings, to measure back clearly and, ultimately, the function of human existence on earth? Substantially, God needs to be frequently present and accompanying to answer all problems that arise, including science development. Spiritual values must continue to be connected with the social values that come. It will help humans not to get out of the signs of their nature. God's attributes, which all contain goodness values, will automatically color all kinds of human actions in leading this mortal world's management.

Henceforth, this Covid19 pandemic could trigger the birth of awareness to place this science in line with religion. God, as the center of all these matters, needs to be put accordingly. Science needs to involve this God (intention) in all aspects, from beginning to end. Inna lillahi wa inna ilaihi rojiun. Complete awareness that everything from Allah and all will return to Him needs to be put continuously for the search for all answers to life, including seeking truth via science.

AKU MENCARIMU, TUHAN!

Di antara riuh rendah suasana

Masih menyesak di ruang otak

Pertanyaan tentang: "dari mana kuberasal?”, "untuk apa kudicipta?” dan

"kemana kan bermuara nanti?"

:masih belum kudapatkan jawaban sebenarnya

Tak lelah tubuh, pikir dan hatiku

Bergerak mencarimu

Katanya Engkau yang berkuasa sepenuhnya

Melahirkan, Menghidupkan dan Mematikan semua yang ada

adalah hak prerogatifmu

Namun di mana sebenarnya dirimu bersemayam

Aku muak dengan banyak versi dari ciptaanmu yang bernama manusia yang membual tentang keberadaanmu

Seolah-olah dirinyalah makhluk yang paling tahu dirimu

bahkan lebih tahu daripada dirimu!

Dalam perjalanan ini, sampai detik ini

yang kutemukan:

Hanya sifat-sifatmu yang 99!

Lalu perkataanmu dalam kitab yang katanya suci itu!

Aku tak mau cuma mengenal penanda-penanda

Sejatimu yang kuingin

Bukan sifat-sifat itu!

Bukan kitab (yang katanya) suci itu!

Aku tak mau bertuhan kepada sifat dan kitab suci yang terbatas itu

Aku mau dirimu yang tak terbatas

Hai engkau yang paling kucari

Tunjukkanlah dirimu yang sesungguhnya

Dan, kita lantas bersua dan berbincang dengan hangat

Tentang pertanyaan-pertanyaanku tadi

mungkin setelah itu, aku dapat tidur tenang 


\section{AM LOOKING FOR YOU, GOD!}

Among the boisterous atmosphere

Still squeezed in the brain space

Questions about: "Where do I come from?" "What I was made for?" and

"Where does it end later?"

: I still don't get the real answer

Not tired of my body, mind, and heart

Move to look for You

He said that You have complete control

Give birth, turn on and turn off everything that exists

is Your prerogative

But where do you actually reside

I am disgusted by the many versions of Your creation called humans

who brag about your existence

It was as if he was the creature who knew You best

even better than You!

On this journey, until this moment

what I found:

Only Your names are 99!

Then your words in that holy book!

I don't want just to know the markers

It's your real who I want

Not those names!

Not the holy book (which he said)!

I do not want to be devoted to nature and limited scriptures

I want you who are limitless

O You the most I seek

Show the real You

And, then we meet and chat warmly

About my questions earlier

maybe after that, I can sleep peacefully

\section{References}

[1] Geman B. The coronavirus is infecting everything in the energy sector. 2020 n.d.

[2] Latif Y. Hitam-Putih Korona. Kompas 2020.

[3] Al Attas SMN. Prolegomena: To The Metaphysics of Islam: An Exposition of the Fundamental Elements of the Worldview of Islam. Malaysia: International Institute of Islamic Thought and Civilization; 2001.

[4] Horowitz IL. Philosophy, Science and the Sociology of Knowledge. New York: Illinois University Press; 1961.

[5] Din H. Islamic Tasawwur. Kedah: Pustaka Salman; 1983. 
[6] Qutb S. Muqawwimāt al-Tashawwur al-Islāmi. Cairo: Dar Syuruq; 1997.

[7] Salleh MS. 7 Prinsip Pembangunan Berteraskan Islam. Kuala Lumpur: Zebra Editions; n.d.

[8] Hudgson M. The Venture of Islam: Conscience and History in World Civilization. Chicago and London: The University of Chicago Press; 1984.

[9] Tamam AM. Islamic Worldview; Paradigma Intelektual Muslim. Akarta: Spirit Media Press; 2017.

[10] Walsh B. The coronavirus outbreak stands to fundamentally change the world. Axios 2020. https://www.axios.com/coronavirus-future-economy-politics-f838d8f109e2-48cd-afa 7-1481d2044e21.html (accessed March 16, 2020).

[11] Brandon S. Man and His Destiny in the Great Religion. Manchester USA: Manchester University Press; 1962.

[12] Azizi K. Kewajiban Membina Kekuatan Jamaah: Rujuk (Surah Al-Anfal, 8:60). Usrah Umum WAP Penang Online 2020. 